\title{
Financial Analysis of Dairy Cattle Farming (Case Study in Pujon District, Malang Regency, Indonesia)
}

\author{
M. Zul Mazwan, Livia Windiana*, Murni Mandasari \\ Department of Agribusiness, University of Muhammadiyah Malang, East Java, Indonesia
}

*Corresponding Authors: Livia Windiana, Department of Agribusiness, University of Muhammadiyah Malang, East Java, Indonesia

\begin{abstract}
Dairy cattle farming in Malang Regency is spread over almost all districts, but the largest population is in Pujon District with 24,097 heads. The purpose of this study was to determine the financial analysis of dairy cattle farming. Sample obtained as many as 56 farmers by using proportional sampling method. The method of analysis used is business feasibility analysis with four criteria, namely Net Present Value (NPV), Internal Rate of Return (IRR), Net B/C Ratio and payback period (PP). The results of the study showed (1) NPV value in group I of Rp16,756,907 and group II Rp47,415,007; (2) Obtained IRR in group I of $4.42 \%$ and group II amounted to $8.19 \%$ greater than the stipulated interest rate of $0.58 \%$; (3) Value of the Net B/C ratio group I of 1.28 and group II of 1.64. So that the business of dairy cattle in Sukomulyo village deserves to be run; (4) the payback period of group I is for 38 months 6 days or 3 years 2 months 6 days. In the group II a period of return on investment for 18 monts 6 days or 1 years 6 monts 6 days.
\end{abstract}

Keywords: Feasibility Study, Cattle farming, Dairy Business

\section{INTRODUCTION}

Livestock is part of the agricultural sub-sector that has an impact on the economy in Indonesia, because most of the population gets a source of income from this sector Rianzani, (2017); (Rompas, Engka and Tolosang, 2015); (Sirajuddin et al., 2019). Increasing population, income, need for animal protein, and increasing public awareness of nutritious food have an impact on increasing demand for livestock and processed products. Meanwhile, the dairy farming business in Indonesia is currently dominated by smallholder farms, with three to six cattle per farmer. East Java is a population center and national dairy cattle production with a total of 265.44 thousand heads or 49.50 percent of the total national dairy cattle population with an average milk production in 2011 to 2015 of 475.10 thousand tons or 54.58 percent of national production. Dairy cattle development in East Java is almost spread in various regions. Malang Regency is one of the largest dairy industries in East Java. The dairy business in Malang Regency is spread over almost all districts, but the largest population of dairy cattle is in Pujon District, with 24,097 heads.

Sukomulyo Village, located in Pujon District, is one of the villages that produces fresh milk. The dairy cattle farming business that is developing in Sukomulyo Village is still on a small scale with 3 to 6 dairy cattle per farmer. The majority of dairy farmers in Sukomulyo Village almost never calculate their entire production costs. The farmer will buy equipment, supplies, medicines for his livestock and add capital only when needed. The farmer does not calculate whether the amount of production costs that have been spent is proportional to the income received. On the other hand, production costs which continue to increase while the selling price of milk does not increase will affect the income of dairy farmers in Sukomulyo Village.

\section{METHOD}

The research location was chosen purposively in the dairy farming area of Sukomulyo Village, Pujon District. Sample obtained as many as 56 farmers by using proportional sampling method. Proportional sampling method was used in this study. With this method, sample was obtained as many as 56 farmers. The method in analyzing the investment feasibility used in this research is Net Present Value (NPV), Internal Rate of Return (IRR) method, Net B / C ratio method and Payback Period.

Net Present Value (NPV) 


$$
\mathrm{NPV}=\sum_{\mathrm{t}=0}^{\mathrm{n}} \frac{\mathrm{Bt}-\mathrm{Ct}}{(1+\mathrm{i})^{\mathrm{i}}}
$$

Information:

$\mathrm{Bt}=$ gross benefit of the project in month $\mathrm{t}$

$\mathrm{Ct}=$ gross cost of the project in month $\mathrm{t}$

$\mathrm{i}=$ interest rate

$\mathrm{n}=$ economic life of the project (12 months)

$\mathrm{t}=$ month $\mathrm{t}(\mathrm{t}=1,2,3, \ldots, 12)$

Internal Rate of Return (IRR)

$$
\mathrm{IRR}=\mathrm{i}_{1}+\frac{\mathrm{NPV}_{1}}{\mathrm{NPV}_{1}-\mathrm{NPV}_{2}}\left(\mathrm{i}_{2}-\mathrm{i}_{1}\right)
$$

Information:

$\mathrm{NPV}_{1}=$ positive Net Present Value

$\mathrm{NPV}_{2}=$ Negative Net Present Value

$\mathrm{i}_{1}=$ Discount rate that generates NPV1

$\mathrm{i}_{2}=$ Discount rate that generates NPV2

Net Benefit Cost Ratio (Net B/C)

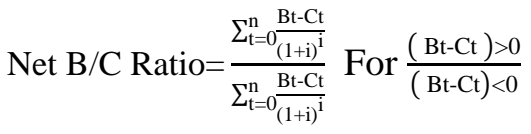

Information:

$\mathrm{Bt}=$ Benefit or monthly net income $(\mathrm{t}=1,2,3, \ldots, 12)$

$\mathrm{Ct}=$ Cost or costs in month $\mathrm{t}$

$\mathrm{i}=$ Interest rate

$\mathrm{T}=$ month (economic time)

Payback Period (PP)

Payback Period $=\frac{\mathrm{I}}{\mathrm{Ab}}$

Information:

I = the amount of investment required

$\mathrm{Ab} \quad=$ net benefit that can be obtained every month

\section{Findings / DisCUSSIONS}

The population of dairy cattle in Sukomulyo Village at the time of the study was 275 heads. Most of the dairy cattle raised in Sukomulyo Village are Fries Holland $(\mathrm{FH})$ dairy cattle. This type of dairy cattle has the characteristics of black and white skin and a small portion of it is brown and white (Dudi and Dhalika 2006); (Herwin et al. 2017). The dairy cattle farming business that is developing in Sukomulyo Village is still on a small scale with 3 to 6 dairy cattle per farmer (Zuliani et al. 2018); . There are no breeders in Sukomulyo Village who maintain adult male dairy cattle. The maintenance of adult male dairy cattle is considered less efficient because of high maintenance costs. Adult male dairy cattle in livestock business are used as breeding males, but currently artificial insemination (IB) facilities are adequate so that they no longer need male dairy cattle for breeding. According to (Runhaar 2017) it is increasingly difficult to combine the preservation of natural livestock with largescale intensive livestock farming.

The lactation period is the period when female dairy cattle are in a productive phase to produce milk. The more feed that is given will increase the milk obtained and extend the life of lactation (Doole 2014); (VandeHaar and St-Pierre 2006); (Reid 1961); (Capper and Cady 2020). The number of lactating dairy cattle in Sukomulyo Village are 196. On average, per farmer has a total of 3.5 dairy cattle with lactation. In general, lactated dairy cattle begin to produce milk when they are three years old and called first lactation. The volume of milk produced during the first lactation is usually not too much, but the volume will continue to increase until it reaches its peak at the time of the fourth and fifth lactations. According to (Tricarico, Kebreab, and Wattiaux 2020) this contributes to meeting the 
demand for milk. Entering the sixth and seventh period the volume of milk produced will slowly decrease. Lactating dairy cattle in the seventh period in Sukomulyo Village had the least amount of 5 heads, because during that period the dairy cattle produced very little milk so the breeders preferred to sell it. On research (Novo et al. 2013) Milk productivity is higher with the use of more types of dairy cattle so that the number of bags of milk being milked is greater.

Income flow

Dairy cattle business in Sukomulyo Village has revenue variables in the form of sales of fresh milk, sales of male calves, sales of female calves, sales of manure, biogas and residual value. The average milk produced by each head of dairy cattle per day is 9.89 liters. The proceeds are sold on cooperatives with an average price of IDR 5,000 per liter. The close relationship between milk collection cooperative and small farmers is very important. The technical support provided by the cooperative and the incentives for collecting milk are important drivers of the preservation and growth of the dairy business (Amamou et al. 2018). Payment from the cooperative for the sale of milk is given once every 15 days or twice a month. Sales of calves (young dairy cattle) which have just been weaning off for an average of three months. Revenue from sales of livestock is based on the price of livestock multiplied by the number of livestock sold.

Not all breeders process dairy cattle waste into manure. The average of manure produced by farmers per month is 13 sacks, each of which weighs $50 \mathrm{~kg}$ and is sold at prices ranging from IDR 25,000 IDR 26,000 per sack. Revenue from biogas is IDR 20,000 per month which is calculated from the amount of costs incurred when using LPG gas.

Expenditure flow

Variable outflows that occur include investment costs and operational costs during the project. Investment expenditure consists of the initial value of the livestock at the start of the project, construction of cattle sheds and purchase of equipment. Operational costs consist of labor costs, electricity, transportation, depreciation, land and building tax costs, forage and concentrate costs. This is in line with research conducted by Davoudkhani et al., (2020) which states that the capital spent includes the need for cattle fodder, labor, depreciation of tools and land as well as variable costs and other fixed costs.

Net Present Value (NPV)

NPV calculations can be divided into two groups. Group I with farmer members who own 3 - 4 dairy cattle. Group II with farmer members owning 5 - 6 dairy cattle.

Table1. NPV using DF 7\% each year (0.58 per month)

\begin{tabular}{|c|c|c|c|c|c|}
\hline \multirow{2}{*}{ Month } & \multirow{2}{*}{ DF 0.58\% } & \multicolumn{2}{|c|}{ Group I } & \multicolumn{2}{c|}{ Group II } \\
\cline { 3 - 6 } & & NB & PV NB & NB & PV NB \\
\hline 1 & 0.994 & $-57,765,586$ & $-57,418,992$ & $-74,874,266$ & $-74,425,020$ \\
\hline 2 & 0.989 & $7,240,676$ & $7,161,029$ & $8,764,116$ & $8,667,710$ \\
\hline 3 & 0.983 & 617,176 & 606,684 & $8,394,052$ & $8,251,353$ \\
\hline 4 & 0.977 & $7,016,863$ & $6,855,475$ & $8,681,657$ & $8,481,979$ \\
\hline 5 & 0.971 & $7,689,471$ & $7,466,477$ & $8,685,438$ & $8,433,560$ \\
\hline 6 & 0.966 & $6,209,471$ & $5,998,349$ & $9,426,104$ & $9,105,617$ \\
\hline 7 & 0.960 & 521,971 & 501,093 & $7,654,536$ & $7,348,355$ \\
\hline 8 & 0.955 & $6,759,471$ & $6,455,295$ & $8,436,952$ & $8,057,289$ \\
\hline 9 & 0.949 & $6,786,321$ & $6,440,219$ & $9,654,118$ & $9,161,758$ \\
\hline 10 & 0.944 & $8,605,846$ & $8,123,919$ & $8,493,786$ & $8,018,134$ \\
\hline 11 & 0.938 & 537,346 & 504,031 & $8,737,993$ & $8,196,238$ \\
\hline 12 & 0.933 & $25,806,996$ & $24,077,928$ & $40,855,338$ & $38,118,030$ \\
\hline & Total & & $16,771,510$ & & $47,415,007$ \\
\hline
\end{tabular}

$\mathrm{DF}=$ degree of freedom; $\mathrm{NB}=$ net benefit; $\mathrm{PV} \mathrm{NB}=$ present value net benefit

The discount factor value is $0.58 \%$. This value is obtained from the Bank Rakyat Indonesia (BRI) deposit interest rate in 2018 which is $7 \%$ then divided by 12 months to get the monthly interest rate. The calculation of PVNB is obtained from the accumulated net benefit from month 1 to month 12. In facing the time value of money, it is multiplied by the DF of $0.58 \%$ which has been determined in the evaluation of the dairy cattle business in Sukomulyo Village. The NPV value in group I was obtained at IDR 16,771,510 which means that the NPV is positive or NPV>0, so that the dairy cattle business 
in Sukomulyo Village in group I is feasible and represents the net income received by farmers for 12 months. This is in line with research conducted by (Durham, Bouma, and Meunier-Goddik 2015) that if NPV > 0 then the business is feasible to run. Group II has an NPV value at a discount rate of $0.58 \%$ which is greater than zero. This shows that the dairy cattle business is worth IDR 47,415,007 to run because it provides net benefits within 12 months. If the dairy cattle business uses debt capital, it is better for the farmer to look for banks that offer the lowest interest rates in order to increase farmer profits and minimize the risk of the livestock business. This is in line with research from (McDonald et al. 2013) who revealed that low-cost dairy cattle farming reduces the financial risk in this case related to expansion.

Internal rate of return

Internal Rate of Return (IRR) is the rate of return on own capital used to run a business. IRR can measure the benefits of own capital to generate profits. Research in group I used a discount factor of $3 \%$ to produce a positive NPV value close to zero and a discount factor of $5 \%$ to produce a negative NPV value close to zero. Group II uses a discount factor of $6 \%$ to produce a positive NPV value close to zero and a discount factor of $9 \%$ to produce a negative NPV value close to zero.

Table2. IRR of Group I dan Group II

\begin{tabular}{|c|c|c|c|c|}
\hline \multirow{2}{*}{ Month } & \multicolumn{2}{|c|}{ Group I } & \multicolumn{2}{c|}{ Group II } \\
\cline { 2 - 5 } & PV NB 3 \% & PV NB 5\% & PV NB 6\% & PV NB 9\% \\
\hline 1 & $-56,090,384$ & $-54,992,838$ & $-70,606,433$ & $-69,333,570$ \\
\hline 2 & $6,827,957$ & $6,567,293$ & $7,800,063$ & $7,379,385$ \\
\hline 3 & 564,716 & 533,240 & $7,051,004$ & $6,480,208$ \\
\hline 4 & $6,230,974$ & $5,774,878$ & $6,875,872$ & $6,146,613$ \\
\hline 5 & $6,636,014$ & $6,028,546$ & $6,488,022$ & $5,645,534$ \\
\hline 6 & $5,197,328$ & $4,632,266$ & $6,645,403$ & $5,617,958$ \\
\hline 7 & 424,363 & 371,122 & $5,090,266$ & $4,187,031$ \\
\hline 8 & $5,333,223$ & $4,576,162$ & $5,289,969$ & $4,235,349$ \\
\hline 9 & $5,198,322$ & $4,377,177$ & $5,715,238$ & $4,440,894$ \\
\hline 10 & $6,402,750$ & $5,283,990$ & $4,739,532$ & $3,584,377$ \\
\hline 11 & 387,964 & 314,347 & $4,604,922$ & $3,390,341$ \\
\hline 12 & $18,090,704$ & $14,374,497$ & $20,305,103$ & $14,544,500$ \\
\hline Total & $5,203,935$ & $-2,159,316$ & $9,998,966$ & $-3,681,373$ \\
\hline IRR & & & & 8.19 \\
\hline
\end{tabular}

PV NB = present value net benefit; IRR = internal rate of return

Based on the feasibility analysis of the dairy cattle business in group I, the IRR value with df of $3 \%$ and $5 \%$ is $4.42 \%$, which is higher than the interest rate that has been determined $(0.58 \%)$, which shows that the dairy cattle business in group I is feasible to run. These results indicate that when the interest rate increases to $4.42 \%$, dairy cattle business in group I is still feasible to run. Meanwhile, the IRR value with $\mathrm{df}$ of $6 \%$ and $9 \%$ in Group II obtained a value of $8.19 \%$ greater than the predetermined interest rate $(0.58 \%)$. This value shows that when the interest rate increases to $8.19 \%$, the dairy cattle business in Sukomulyo Village in Group II is still feasible to run. This is in line with research (Dolewikou, Sumekar, and Setiadi 2016) dan (Becker et al. 2007) which says that the business is profitable if the return on present value is greater than the bank interest rate. Tricarico et al., (2020) added that owning livestock in low-income countries could significantly improve nutrition and economic yields.

\section{Net B/C}

Based on the calculation of the Net $\mathrm{B} / \mathrm{C}$ ratio in group $\mathrm{I}$, the result is 1.28 , which means that the Net $\mathrm{B} / \mathrm{C}$ ratio is positive or Net $\mathrm{B} / \mathrm{C}$ ratio $>0$. This value shows that the dairy cattle farmers in group I will get an additional income of IDR 1.28 from each. IDR 1.00 issued. In group II, a positive Net B/C ratio was obtained, which was 1.64 , which means that for every IDR 1.00 spent by group II, dairy cattle breeders will get additional income of IDR 1.64. Ownership of cattle can also affect social and economic welfare, including increased milk consumption, increased crop production using manure, increased income from sales, and other positive impacts in increasing local economic growth (Tricarico, Kebreab, and Wattiaux 2020). 
Table3. Net B/C ratio in Group I and Group II

\begin{tabular}{|c|c|c|c|c|c|}
\hline \multirow{2}{*}{ Month } & \multirow{2}{*}{ DF 0.58\% } & \multicolumn{2}{|c|}{ Group I } & \multicolumn{2}{c|}{ Group II } \\
\cline { 3 - 6 } & & NB & PV NB & NB & PV NB \\
\hline 1 & 0.994 & $-57,765,586$ & $-57,418,992$ & $-74,874,266$ & $-74,425,020$ \\
\hline 2 & 0.989 & $7,240,676$ & $7,161,029$ & $8,764,116$ & $8,667,710$ \\
\hline 3 & 0.983 & 617,176 & 606,684 & $8,394,052$ & $8,251,353$ \\
\hline 4 & 0.977 & $7,016,863$ & $6,855,475$ & $8,681,657$ & $8,481,979$ \\
\hline 5 & 0.971 & $7,689,471$ & $7,466,477$ & $8,685,438$ & $8,433,560$ \\
\hline 6 & 0.966 & $6,209,471$ & $5,998,349$ & $9,426,104$ & $9,105,617$ \\
\hline 7 & 0.960 & 521,971 & 501,093 & $7,654,536$ & $7,348,355$ \\
\hline 8 & 0.955 & $6,759,471$ & $6,455,295$ & $8,436,952$ & $8,057,289$ \\
\hline 9 & 0.949 & $6,786,321$ & $6,440,219$ & $9,654,118$ & $9,161,758$ \\
\hline 10 & 0.944 & $8,605,846$ & $8,123,919$ & $8,493,786$ & $8,018,134$ \\
\hline 11 & 0.938 & 537,346 & 504,031 & $8,737,993$ & $8,196,238$ \\
\hline 12 & 0.933 & $25,806,996$ & $24,077,928$ & $40,855,338$ & $38,118,030$ \\
\hline & NPV (+) & $74,190,503$ & & & $121,840,027$ \\
\hline & NPV (-) & $-57,765,586$ & & & $-74,425,020$ \\
\hline & Net B/C ratio & 1.28 & & & 1.64 \\
\hline
\end{tabular}

$\mathrm{DF}=$ degree of freedom; NB = net benefit; PV NB = present value net benefit; NPV = net present value; Net B/C Ratio = Net Benefit/Cost Ratio

Payback period

Based on the calculation of the payback period, the investment return period in group I is 38 months 6 days or 3 years 2 months 6 days. In group II, the investment return period is 18 months 6 days or 1 year 6 months 6 days. The period of return on investment in group II is faster when compared to group I. This shows that the dairy cattle business in group II is declared better because the faster the return on investment, the better the business to run. According to Mahmoodieh et al., (2013), The average gross income and total cost of production are lower for small and medium scale cattle farm compared to large scale cattle farms.

Based on the calculation of NPV, IRR, Net B / C Ratio, and Payback Period, the dairy cattle business is feasible to run. The larger the scale of the dairy cattle business, the greater the benefits that will be obtained.

Table4. Payback Period in Group I dan Group II

\begin{tabular}{|c|c|c|}
\hline Calculation & Group I & Group II \\
\hline Investation & $64,516,300$ & $82,129,528$ \\
\hline Net Benefit & $1,668,878$ & $4,409,152$ \\
\hline Payback Period & 38.6 & 18.6 \\
\hline
\end{tabular}

\section{CONCLUSION}

The factors that influence the interest of rural youth in farming are prestige factors, that are having the same honor as other jobs in terms of profession and honor which are the same as other jobs in the selection of a prospective spouse. The second factor that influence the interest of rural youth in farming is the future guarantee, that are life insurance and future guarantee. The third factor that affects is the parental land area. An interesting finding is that narrower the land area, the greater the interest of rural youth in farming. This is in line with the condition of the local culture, the hereditary inheritance of the land which is getting smaller and smaller. While the privilege factor, parental encouragement, education level, education suitability, commodity value and income do not significantly influence the interest of rural youth to farm.

\section{REFERENCES}

[1] Amamou, Hajer et al. 2018. "Climate Change-Related Risks and Adaptation Strategies as Perceived in Dairy Cattle Farming Systems in Tunisia." Climate Risk Management 20(March 2017): 38-49. https://doi.org/ 10.1016/j.crm.2018.03.004.

[2] Becker, K. M., R. L. Parsons, J. Kolodinsky, and G. N. Matiru. 2007. "A Cost and Returns Evaluation of Alternative Dairy Products to Determine Capital Investment and Operational Feasibility of a Small-Scale Dairy Processing Facility." Journal of Dairy Science 90(5): 2506-16.

[3] Capper, Judith L., and Roger A. Cady. 2020. "The Effects of Improved Performance in the U.S. Dairy Cattle Industry on Environmental Impacts between 2007 and 2017.” Journal of Animal Science 98(1): 1-14. 
[4] Davoudkhani, M. et al. 2020. "Economic Optimization of Feeding and Shipping Strategies in PigFattening Using an Individual-Based Model.” Agricultural Systems 184(March): 102899. https://doi.org/10.1016/j.agsy .2020.102899.

[5] Dolewikou, R. L., W. Sumekar, and A. Setiadi. 2016. "The Profitability Analysis of Dairy Cattle Business on the Group of Dairy Farmers in West Ungaran District Semarang Regency.” Journal of the Indonesian Tropical Animal Agriculture 41(4): 216-23.

[6] Doole, G. J. 2014. "Economic Feasibility of Supplementary Feeding on Dairy Farms in the Waikato Region of New Zealand." New Zealand Journal of Agricultural Research 57(2): 90-99.

[7] Dudi, Dedi Rahmat, and Tidi Dhalika. 2006. "Evaluasi Potensi Genetik Sapi Perah Fries Holland ( FH ) Di Koperasi Serba Usaha ( KSU ) Tandangsari Kabupaten Sumedang ( Evaluation of Dairy Cattle Genetic Potency of Fries Holland ( FH ) in KSU Tandangsari Sumedang )." Jurnal Ilmu Ternak 6(1): 42-47.

[8] Durham, Catherine A., Andrea Bouma, and Lisbeth Meunier-Goddik. 2015. "A Decision-Making Tool to Determine Economic Feasibility and Break-Even Prices for Artisan Cheese Operations." Journal of Dairy Science 98(12): 8319-32.

[9] Herwin, Pisestyani, Mirnawati Sudarwanto, Retno Wulansari, and Afton Atabany. 2017. "Subclinal Hypocalcaemia as a Predisposing Factor of Subclinical Mastitis in Dairy Cow in West Java Province, Indonesia Subclinal Hypocalcaemia as a Predisposing Factor of Subclinical Mastitis in Dairy Cow in West Java Province, Indonesia." 4531(January): 1-12.

[10] Mahmoodieh, Mohammad Reza, Yaser Rahimian, Fatemeh Asgarian, and Mohammad Reza Valiollhi. 2013. "The Economic Evaluation and Financial Analysis of Dairy Farms in Chahar Mahal and Bakhtiari Province ( Case Study of Shahrekord County )." 1(3): 67-71.

[11] McDonald, R., L. Shalloo, K. M. Pierce, and B. Horan. 2013. "Evaluating Expansion Strategies for Startup European Union Dairy Farm Businesses." Journal of Dairy Science 96(6): 4059-69.

[12] Novo, André Monteiro et al. 2013. "Feasibility and Competitiveness of Intensive Smallholder Dairy Farming in Brazil in Comparison with Soya and Sugarcane: Case Study of the Balde Cheio Programme.” Agricultural Systems 121: 63-72.

[13] Reid, J. T. 1961. "Problems of Feed Evaluation Related to Feeding of Dairy Cows." Journal of Dairy Science 44(11): 2122-33.

[14] Rianzani, Citra. 2017. "Analisis Kelayakan Finansial, Nilai Tambah Dan Strategi Pengembangan Usaha Ternak Sapi Perah Kelompok Tani Naeng Mukti Di Kecamatan Air Naningan Kabupaten Tanggamus." Universitas lampung.

[15] Rompas, Jui, Deisy Engka, and Krest Tolosang. 2015. "Potensi Sektor Pertanian Dan Pengaruhnya Terhadap Penyerapan Tenaga Kerja Di Kabupaten Minahasa Selatan.” Jurnal Berkala Ilmiah Efisiensi 15(04): 124-36.

[16] Runhaar, Hens. 2017. "Governing the Transformation towards 'Nature-Inclusive' Agriculture: Insights from the Netherlands." International Journal of Agricultural Sustainability 15(4): 340-49.

[17] Sirajuddin, Sitti Nurani, Hastang, Veronica Sri Lestari, and Rosmawaty. 2019. "Livestock Ecology Research on Institution and Traditional Sharing Systems in Cattle Farms." EurAsian Journal of BioSciences 13(1): 239-44.

[18] Tricarico, J. M., E. Kebreab, and M. A. Wattiaux. 2020. "MILK Symposium Review: Sustainability of Dairy Production and Consumption in Low-Income Countries with Emphasis on Productivity and Environmental Impact." Journal of Dairy Science 103(11): 9791-9802. http://dx.doi.org/10.3168/ jds.2020-18269.

[19] VandeHaar, M. J., and N. St-Pierre. 2006. "Major Advances in Nutrition: Relevance to the Sustainability of the Dairy Industry." Journal of Dairy Science 89(4): 1280-91.

[20] Zuliani, A. et al. 2018. "A Survey of Selected Animal-Based Measures of Dairy Cattle Welfare in the Eastern Alps: Toward Context-Based Thresholds.” Journal of Dairy Science 101(2): 1428-36.

\section{AUTHORS' BIOGRAPHY}

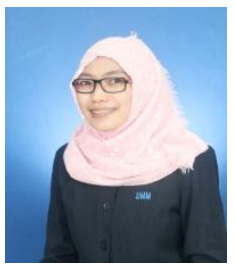

Livia Windiana, SP. M.Agr. is lecturer in Agribusiness Department, University of Muhammadiyah Malang, East Java - Indonesia. Graduated as an undergraduate from Agribusiness Department of Agriculture Faculty, University of Brawijaya, Malang, Indonesia (2010). Graduated from Postgraduate of Agribusiness, University of Muhammadiyah Malang, Malang, Indonesia (2012). Research interest in marketing management, green marketing. 


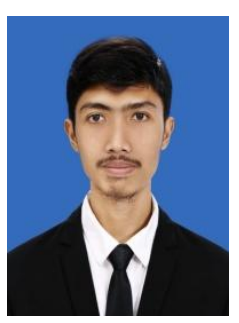

M. Zul Mazwan, SP. M.Sc. is lecturer in Agribusiness Department, University of Muhammadiyah Malang, East Java - Indonesia. Graduated as an undergraduate from Agribusiness Department of Agriculture Faculty, University of Brawijaya, Malang, Indonesia (2015). Graduated from Postgraduate of Agricultural Economics, Universitas Gadjah Mada, Yogyakarta, Indonesia (2018). Research interest in agricultural economics, young farmer, farmer welfare.

Citation: Livia Windiana, et.al., "Financial Analysis of Dairy Cattle Farming (Case Study in Pujon District, Malang Regency, Indonesia)" International Journal of Managerial Studies and Research (IJMSR), vol 9, no. 2, 2021, pp. 11-17. doi: https://doi.org/10.20431/2349-0349.0902002.

Copyright: (c) 2021 Authors. This is an open-access article distributed under the terms of the Creative Commons Attribution License, which permits unrestricted use, distribution, and reproduction in any medium, provided the original author and source are credited. 